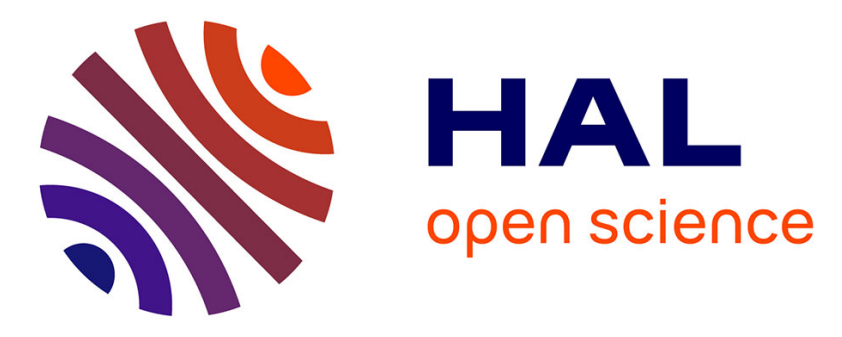

\title{
Whole body leucine flux in HIV-infected patients treated with or without protease inhibitors
}

Magali Prod'Homme, Cécile Rochon, Michelle M. Balage, Henri Laurichesse, Igor Tauveron, Claude Champredon, Philippe Thieblot, Jean Beytout, Jean Grizard

\section{To cite this version:}

Magali Prod'Homme, Cécile Rochon, Michelle M. Balage, Henri Laurichesse, Igor Tauveron, et al.. Whole body leucine flux in HIV-infected patients treated with or without protease inhibitors. AJP - Endocrinology and Metabolism, 2006, 290 (4), pp.E685-E693. 10.1152/ajpendo.00067.2005 . hal02658572

\section{HAL Id: hal-02658572 \\ https://hal.inrae.fr/hal-02658572}

Submitted on 30 May 2020

HAL is a multi-disciplinary open access archive for the deposit and dissemination of scientific research documents, whether they are published or not. The documents may come from teaching and research institutions in France or abroad, or from public or private research centers.
L'archive ouverte pluridisciplinaire HAL, est destinée au dépôt et à la diffusion de documents scientifiques de niveau recherche, publiés ou non, émanant des établissements d'enseignement et de recherche français ou étrangers, des laboratoires publics ou privés. 
Magali Prod'homme, Cécile Rochon, Michèle Balage, Henri Laurichesse, Igor

Tauveron, Claude Champredon, Philippe Thieblot, Jean Beytout and Jean

Grizard

Am J Physiol Endocrinol Metab 290:685-693, 2006. First published Oct 25, 2005;

doi:10.1152/ajpendo.00067.2005

You might find this additional information useful...

This article cites 47 articles, 27 of which you can access free at:

http://ajpendo.physiology.org/cgi/content/full/290/4/E685\#BIBL

Updated information and services including high-resolution figures, can be found at:

http://ajpendo.physiology.org/cgi/content/full/290/4/E685

Additional material and information about AJP - Endocrinology and Metabolism can be found at:

http://www.the-aps.org/publications/ajpendo

This information is current as of September 2, 2010 .

AJP - Endocrinology and Metabolism publishes results of original studies about endocrine and metabolic systems on any level of organization. It is published 12 times a year (monthly) by the American Physiological Society, 9650 Rockville Pike, Bethesda MD 20814-3991. Copyright @ 2006 by the American Physiological Society. ISSN: 0193-1849, ESSN: 1522-1555. Visit our website at http://www.the-aps.org/. 


\title{
Whole body leucine flux in HIV-infected patients treated with or without protease inhibitors
}

\author{
Magali Prod'homme, ${ }^{1}$ Cécile Rochon, ${ }^{1}$ Michèle Balage, ${ }^{1}$ Henri Laurichesse,${ }^{2}$ Igor Tauveron, ${ }^{3}$ \\ Claude Champredon, ${ }^{1}$ Philippe Thieblot, ${ }^{3}$ Jean Beytout, ${ }^{2}$ and Jean Grizard ${ }^{1}$ \\ ${ }^{1}$ Unité de Nutrition et Métabolisme Protéique, Institut National de la Recherche Agronomique, \\ Clermont-Ferrand/Theix, Saint-Genès-Champanelle and Centre de Recherche en Nutrition Humaine, \\ Clermont-Ferrand; ${ }^{2}$ Service des Maladies Infectieuses et Tropicales and ${ }^{3}$ Service d'Endocrinologie \\ et Maladies Métaboliques, Centre Hospitalier Universitaire de Clermont-Ferrand, Clermont-Ferrand, France
}

Submitted 17 February 2005; accepted in final form 19 October 2005

\begin{abstract}
Prod'homme, Magali, Cécile Rochon, Michèle Balage, Henri Laurichesse, Igor Tauveron, Claude Champredon, Philippe Thieblot, Jean Beytout, and Jean Grizard. Whole body leucine flux in HIV-infected patients treated with or without protease inhibitors. Am J Physiol Endocrinol Metab 290: E685-E693, 2006. First published October 25, 2005; doi:10.1152/ajpendo.00067.2005.-The present study was carried out to assess the effects of protease inhibitor (PI) therapy on basal whole body protein metabolism and its response to acute amino acid-glucose infusion in 14 human immunodeficiency virus (HIV)-infected patients. Patients treated with PIs (PI+, 7 patients) or without PIs (PI-, 7 patients) were studied after an overnight fast during a 180-min basal period followed by a 140-min period of amino acid-glucose infusion. Protein metabolism was investigated by a primed constant infusion of $\mathrm{L}-\left[1-{ }^{13} \mathrm{C}\right]$ leucine. Dual-energy X-ray absorptiometry for determination of fat-free mass (FFM) and body fat mass measured body composition. In the postabsorptive state, whole body leucine balance was 2.5 times $(P<0.05)$ less negative in the $\mathrm{PI}+$ than in the PI- group. In HIV-infected patients treated with PIs, the oxidative leucine disposal during an acute amino acid-glucose infusion was lower $(0.58 \pm 0.09$ vs. $0.81 \pm 0.07 \mu \mathrm{mol} \cdot \mathrm{kg}$ $\mathrm{FFM}^{-1} \cdot \mathrm{min}^{-1}$ using plasma $\left[{ }^{13} \mathrm{C}\right]$ leucine enrichment, $P=0.06$; or $0.70 \pm 0.10$ vs. $0.99 \pm 0.08 \mu \mathrm{mol} \cdot \mathrm{kg} \mathrm{FFM}^{-1} \cdot \mathrm{min}^{-1}$ using plasma $\left[{ }^{13} \mathrm{C}\right]$ ketoisocaproic acid enrichment, $P=0.04$ in PI+ and PIgroups, respectively) than in patients treated without PIs. Consequently, whole body nonoxidative leucine disposal (an index of protein synthesis) and leucine balance $(0.50 \pm 0.10$ vs. $0.18 \pm 0.06$ $\mu \mathrm{mol} \cdot \mathrm{kg} \mathrm{FFM} \cdot{ }^{-1} \cdot \mathrm{min}^{-1}$ in $\mathrm{PI}+$ and $\mathrm{PI}-$ groups respectively, $P<$ $0.05)$ were significantly improved during amino acid-glucose infusion in patients treated with PIs. However, whereas the response of whole body protein anabolism to an amino acid-glucose infusion was increased in HIV-infected patients treated with PIs, any improvement in lean body mass was detected.
\end{abstract}

leucine kinetics; protease inhibitor therapy; human immunodeficiency virus infection; amino acid requirements

THE INTRODUCTION OF PROTEASE INHIBITORS (PIs) is a landmark event in the history of HIV disease treatment and has greatly improved the survival and quality of life of patients. However, patients with HIV diseases under PI therapy for long periods of time frequently develop lipid and glucose metabolism alterations such as lipodystrophy, including peripheral lipoatrophy and increased visceral fat, hyperlipidemia (i.e., elevated plasma triglycerides and cholesterol), diabetes mellitus, insulin resistance, and cardiovascular diseases $(19,32,37)$.

Address for reprint requests and other correspondence: M. Balage, UNMP INRA, Clermont-Ferrand-Theix, 63122 Saint-Genès-Champanelle, France (balage@clermont.inra.fr).
Moreover, muscle wasting remains a significant clinical problem in patients with acquired immune deficiency syndrome (AIDS), even under PI therapy $(15,38)$. AIDS is characterized by a predominant loss of lean body tissue (22), which is considered as a major predictor of morbidity and mortality $(20,21)$. Multiple factors in different combinations contribute to lean body mass loss, including reduced food intake, nutrient malabsorption, and abnormal utilization and excretion of nutrients. In addition, elevated resting energy expenditure and specific disturbances in protein turnover might be responsible for decreased lean body mass. An increased whole body protein turnover has been reported in the postabsorptive state in HIV-infected patients compared with healthy control subjects $(11,17,26,48)$. In contrast, a decrease in whole body protein turnover has been observed in the fed state in some $(31,40)$ but not all studies $(26,39)$, which suggests that there is an altered response to food intake.

Contrasting with glucose and lipid metabolism, there is no information available on the effect of PI therapy on protein metabolism in HIV-infected patients. A better understanding of the regulation of protein metabolism in HIV-infected patients is needed to prevent losses of lean body mass and to establish dietary protein requirements. This study has been therefore initiated to investigate the effects of PI therapy on whole body protein turnover in HIV-infected patients. For this purpose, we compared whole body leucine kinetics in two groups of HIVinfected patients treated with (PI+) or without (PI-) PIs. The patients were studied $l$ ) in the postabsorptive state to determine the effect of PI therapy on the basal whole body leucine metabolism and 2) during an acute intravenous amino acidglucose infusion to evaluate a possible effect of PI treatment on the response of whole body metabolism to an anabolic state.

\section{MATERIALS AND METHODS}

Patients. The protocol was approved by the local ethics committee (Comité Consultatif pour la Protection des Personnes en Recherche Biomédicale pour la Région Auvergne). Each patient provided written informed consent before enrollment. The study population consisted of 14 male patients recruited from the Department of Infectious Diseases at the University Hospital in Clermont-Ferrand, France. On the basis of the ELISA and Western blot assays, all were HIV seropositive. History of clinical events was recorded for all patients, and a physical examination was performed at the time of the study.

The costs of publication of this article were defrayed in part by the payment of page charges. The article must therefore be hereby marked "advertisement" in accordance with 18 U.S.C. Section 1734 solely to indicate this fact. 
Only patients who had been free of any opportunistic infection and persisting fever for a period $\geq 6$ mo before enrollment were included. Patients with diarrhea or loss of appetite were excluded. No patient had ever been given any testosterone derivatives or human growth hormone.

Two groups of patients were selected on the basis of their therapy: patients treated with a combination therapy of three agents, including at least one PI (patients treated with PIs, PI+ group; $n=7$ ) and patients under an antiretroviral regimen that did not include PIs (patients treated without PIs, PI- group; $n=7$ ). PI- patients were treated with a combination of nucleosidic reverse transcriptase inhibitors (NRTIs) and/or nonnucleosidic reverse transcriptase inhibitor (NNRTI; Table 1). Each group exhibited the same known duration of HIV infection ( $7 \pm 2 \mathrm{yr}$ in PI - and $7 \pm 1 \mathrm{yr}$ in PI+ group) and antiretroviral treatments $(4.1 \pm 1.4 \mathrm{yr}$ in $\mathrm{PI}-$ and $3.6 \pm 0.6 \mathrm{yr}$ in PI+ group). Patients underwent the present therapy for $1.6 \mathrm{yr}(0.5 \mathrm{yr}$ minimum, $3 \mathrm{yr}$ maximum) in the PI- group and $1.9 \mathrm{yr}(1 \mathrm{yr}$ minimum, $2.5 \mathrm{yr}$ maximum) in the PI + group. PIs were prescribed when the previous combination therapy failed, i.e., when plasma virus load increased significantly $\left(>0.5 \log _{10}\right.$ copies/ml) and CD4 number decreased (nadir CD4 were $342 \pm 36$ and $90 \pm 41$ CD4 cell count $/ \mathrm{mm}^{3}$, respectively, in PI- and PI + groups; means $\pm \mathrm{SE}, P<$ $0.001)$. This could explain why the CD4 cell counts tend to be lower $(P=0.07)$ in the PI+ group than in the PI - group, although the viral loads did not differ between groups (Table 1). Weight history was available for all patients. Before initiation of the present therapy (i.e., from the first diagnosis to beginning the present therapy), only one subject had $>10 \%$ weight loss (in PI+ group), two had $>5 \%$ weight loss ( 1 in each group), four had $<5 \%$ weight loss ( 1 in PI + group and 3 in PI- group), and seven had gained weight (0.9-13\%). PI therapy resulted in a body weight gain $(65.7 \pm 1.9$ vs. $69.8 \pm 1.7 \mathrm{~kg}$ before and after PI therapy; means $\pm \mathrm{SE}, P<0.05$ by paired $t$-test). Indeed, only one patient lost weight $(-1.5 \%)$, whereas the other subjects gained weight $(2.1-6.1 \%)$ in the PI+ group. In the PI- group, the present therapy did not change mean body weight $(74.5 \pm 6.3$ vs. $72.7 \pm 5.3 \mathrm{~kg}$ before and after the present therapy period; not significant by paired $t$-test); one patient had $>10 \%$ weight loss, two had $<5 \%$ weight loss, and four gained weight $(0.7-4.7 \%)$.

Dietary control. Each volunteer was given a questionnaire, with a dietitian assigned to define the volunteer's usual dietary intake. Diet survey analyses of usual intake indicated that the subjects in the two groups consumed similar and adequate amounts of protein, carbohydrate, and fat before the study (PI+ patients: protein, $7 \pm 1 \mathrm{kcal} \cdot \mathrm{kg}$ body $\mathrm{wt}^{-1} \cdot$ day $^{-1}$; carbohydrate, $17 \pm 2 \mathrm{kcal} \cdot \mathrm{kg}$ body $\mathrm{wt}^{-1} \cdot \mathrm{day}^{-1}$; fat, $15 \pm 3 \mathrm{kcal} \cdot \mathrm{kg}$ body $\mathrm{wt}^{-1} \cdot \mathrm{day}^{-1}$; PI - patients: protein, $7 \pm 1$ $\mathrm{kcal} \cdot \mathrm{kg}$ body $\mathrm{wt}^{-1} \cdot \mathrm{day}^{-1}$; carbohydrate, $19 \pm 3 \mathrm{kcal} \cdot \mathrm{kg}$ body $\mathrm{wt}^{-1} \cdot \mathrm{day}^{-1}$; fat, $18 \pm 5 \mathrm{kcal} \cdot \mathrm{kg}$ body $\mathrm{wt}^{-1} \cdot \mathrm{day}^{-1}$ ). Therefore, the possible effect of treatment could not be the result of differences in food intake.

Materials. L- $\left[1-{ }^{13} \mathrm{C}\right]$ leucine and $\left[{ }^{13} \mathrm{C}\right] \mathrm{NaHCO}_{3}$ (99\% pure; MassTrace, Woburn, MA) were prepared aseptically in water (at final concentrations of 75.6 and $11.7 \mu \mathrm{mol} / \mathrm{ml}$, respectively). A commercially available amino acid solution (Primène $50 \mathrm{~g} / \mathrm{l}$; Baxter, Maurepas, France) contained amino acids in the following concentrations (in $\mu \mathrm{mol} / \mathrm{ml}$ ): L-leucine, 38.17; L-isoleucine, 25.57; L-valine, 32.48; L-lysine, 37.67; L-methionine, 8.05; L-phenylalanine, 12.73; L-threonine, 15.55; L-tryptophane, 4.90; L-alanine, 44.94; L-arginine, 24.14; L-aspartic acid, 22.56; L-cysteine, 10.16 (chlorydrate); L-glutamic acid, 34.01; glycine, 26.67; taurine, 2.40; L-histidine, 12.26; L-proline, 13.05; L-serine, 19.05; L-tyrosine, 2.49; and L-ornithine, 8.56. A beet-derived glucose solution ( $100 \mathrm{~g} / \mathrm{l}$, with a low natural abundance of ${ }^{13} \mathrm{C}$ ) was obtained from Braun (St. Gallen, Germany). It was verified in preliminary experiments that the natural abundance in glucose and amino acids infused in conjunction with insulin had no effect on basal ${ }^{13} \mathrm{C}$ enrichments in plasma leucine and expired $\mathrm{CO}_{2}$. This suggests that the compounds infused did not artifactually modify ${ }^{13} \mathrm{C}$ enrichments during $\left[{ }^{13} \mathrm{C}\right]$ leucine infusion.

Experimental procedure. All patients were studied in a postabsorptive state after a 12-h overnight fast. A sampling catheter (Venflon 2, 20G; Viggo, Helsingborg, Sweden) was inserted into a dorsal hand vein in a retrograde fashion. Another catheter was placed in a contralateral forearm vein for infusions.

Each infusion protocol (Fig. 1) consisted of a 320-min study period, throughout which $\mathrm{L}-\left[1-{ }^{13} \mathrm{C}\right]$ leucine was infused at a constant rate $\left(0.18 \pm 0.008 \mu \mathrm{mol} \cdot \mathrm{kg}^{-1} \cdot \mathrm{min}^{-1}\right)$ after priming doses of $\left[{ }^{13} \mathrm{C} \mathrm{NaHCO}_{3}(105 \mu \mathrm{mol})\right.$ and $\mathrm{L}-\left[1-{ }^{13} \mathrm{C}\right]$ leucine $(530 \mu \mathrm{mol})$. Each patient was first studied during a 180-min basal period to determine the postabsorptive (basal period) whole body leucine kinetics. In a second 140-min period (infused period), a continuous infusion of the amino acid solution Primène $\left(1 \mathrm{ml} \cdot \mathrm{kg}^{-1} \cdot \mathrm{h}^{-1}\right.$, i.e., $0.05 \mathrm{~g}$ amino

Table 1. Characteristics of patients before the experiment

\begin{tabular}{|c|c|c|c|c|c|c|c|}
\hline & \multirow[b]{2}{*}{ Age, yr } & \multirow[b]{2}{*}{ Height, m } & \multirow[b]{2}{*}{ BMI, $\mathrm{kg} / \mathrm{m}^{2}$} & \multirow{2}{*}{$\begin{array}{c}\text { Plasma Virus } \\
\text { Load, log } 10 \\
\text { copies } / \mathrm{ml}\end{array}$} & \multirow{2}{*}{$\begin{array}{l}\mathrm{CD} 4, \text { cell } \\
\text { count } / \mathrm{m}^{3}\end{array}$} & \multicolumn{2}{|l|}{ Current Therapy, mg/day } \\
\hline & & & & & & HAART & Other drugs \\
\hline \multirow{7}{*}{$\begin{array}{l}\text { Group PI- } \\
\quad(n=7)\end{array}$} & 36 & 1.80 & 23.8 & 3.00 & 655 & AZT $(600)+\operatorname{ddC}(2.25)$ & None \\
\hline & 27 & 1.71 & 18.8 & 1.60 & 950 & NVP (400) + ddC (2.25) & None \\
\hline & 53 & 1.68 & 22.6 & 2.72 & 644 & NVP $(400)+$ d4T (80) + ddI (400) & None \\
\hline & 38 & 1.83 & 23.5 & 2.11 & 360 & $\operatorname{AZT}(600)+3 \mathrm{TC}(300)$ & None \\
\hline & 37 & 1.85 & 22.5 & 1.70 & 1,235 & $\mathrm{~d} 4 \mathrm{~T}(80)+\mathrm{ddI}(400)$ & None \\
\hline & 53 & 1.86 & 28.0 & 2.27 & 313 & $\mathrm{~d} 4 \mathrm{~T}(80)+\mathrm{ddI}(400)$ & $\begin{array}{c}\text { Fenofibrate }(200)+ \\
\text { allopurinol }(100)\end{array}$ \\
\hline & 41 & 1.80 & 18.7 & 1.70 & 798 & $\mathrm{~d} 4 \mathrm{~T}(80)+\mathrm{ddI}(400)+\mathrm{NVP}(400)$ & bupremorphine (8) \\
\hline Means $\pm \mathrm{SE}$ & $41 \pm 4$ & $1.79 \pm 0.03$ & $22.6 \pm 1.2$ & $2.16 \pm 0.20$ & $708 \pm 122$ & & \\
\hline \multirow{7}{*}{$\begin{array}{l}\text { Group PI+ } \\
\quad(n=7)\end{array}$} & 47 & 1.71 & 21.0 & 2.70 & 398 & $\mathrm{~d} 4 \mathrm{~T}(80)+3 \mathrm{TC}(300)+\operatorname{IDV}(2,400)$ & None \\
\hline & 34 & 1.59 & 25.0 & 2.30 & 671 & AZT $(600)+3$ TC (300) + RTV (600) & None \\
\hline & 44 & 1.72 & 23.0 & 1.70 & 340 & AZT $(600)+3 \mathrm{TC}(300)+\operatorname{IDV}(2,400)$ & Cotrimoxazole (800) \\
\hline & 35 & 1.78 & 20.5 & 2.70 & 348 & AZT $(600)+3 \mathrm{TC}(300)+\operatorname{IDV}(2,400)$ & Cotrimoxazole (800) \\
\hline & 32 & 1.73 & 24.4 & 2.30 & 559 & AZT $(600)+3$ TC $(300)+$ RTV $(800)$ & None \\
\hline & 45 & 1.78 & 23.7 & 1.60 & 517 & AZT $(600)+3 \mathrm{TC}(300)+\operatorname{IDV}(2,400)$ & None \\
\hline & 64 & 1.80 & 22.1 & 1.70 & 232 & $\mathrm{AZT}(600)+3 \mathrm{TC}(300)+\mathrm{RTV}(600)$ & $\begin{array}{l}\text { Fluoxetine }(20), \\
\text { lormetazepam (2), } \\
\text { alfuzosine }(2.5)\end{array}$ \\
\hline Means $\pm \mathrm{SE}$ & $43 \pm 4$ & $1.73 \pm 0.03$ & $22.8 \pm 0.6$ & $2.14 \pm 0.18$ & $438 \pm 57$ & & \\
\hline
\end{tabular}

BMI, body mass index; HAART, highly active antiretroviral therapy; PI-, nonprotease inhibitor treated; PI + , protease inhibitor treated. AZT, zidovudine; ddC, zalcitabine; NVP, nevirapine; d4T, stavudine; ddI, didanosine; 3TC, lamivudine; IDV, indinavir; RTV, ritonavir. 




Fig. 1. Experimental protocol. Subjects underwent a 180-min basal period followed by a 140-min period of continuous infusion of amino acid mixture and glucose. A primed injection of $\mathrm{L}-\left[1-{ }^{13} \mathrm{C}\right]$ leucine and $\left[{ }^{13} \mathrm{C}\right]$ bicarbonate at time $O$ followed by a constant infusion of $\mathrm{L}-\left[1-{ }^{13} \mathrm{C}\right]$ leucine was used to determine leucine kinetics during both basal and amino acid-glucose infusion periods. Arrows indicate blood sampling and expired-air collections.

acids $\left.\cdot \mathrm{kg}^{-1} \cdot \mathrm{h}^{-1}\right)$ and glucose solution $\left(1 \mathrm{ml} \cdot \mathrm{kg}^{-1} \cdot \mathrm{h}^{-1}\right.$, i.e., $0.1 \mathrm{~g}$ glucose $\cdot \mathrm{kg}^{-1} \cdot \mathrm{h}^{-1}$ ) was administrated simultaneously with the $\mathrm{L}-[1-$ ${ }^{13} \mathrm{C}$ ]leucine (using separate peristaltic pumps: Vip 2; Becton Dickinson, St. Etienne de St. Geoirs, France) to determine the whole body leucine kinetic response to an acute amino acid-glucose infusion.

Sampling. Arterialized blood (obtained by placing the forearm and hand in a heating box at $60^{\circ} \mathrm{C}$ ) was taken from the dorsal hand catheter at -30 and -10 min before the basal period, at 130, 150, and $170 \mathrm{~min}$ during the basal period and at 260, 280, 300, and $320 \mathrm{~min}$ during amino acid-glucose infusions (i.e., 80, 100, 120, and $140 \mathrm{~min}$ after beginning amino acid-glucose infusion; Fig. 1). Blood samples were collected in heparinized tubes and centrifuged at $4^{\circ} \mathrm{C}$, and the resulting plasma was stored at $-20^{\circ} \mathrm{C}$ for subsequent analyses. Breath samples were collected during 4-min periods at the last three sampling points during the basal period and the last four sampling points during the amino acid-glucose infusion. The expired breath was dried on $\mathrm{CaCl}_{2}$ and passed through a gasometer (Slonic, Schlumberger, France) for volume determination. A fraction of the expired-air sample was drawn into a bottle filled with a soda lime-sodium hydroxide mixture $(1: 4 \mathrm{wt} / \mathrm{wt})$ to measure the $\mathrm{CO}_{2}$ content. Another fraction was collected into evacuated glass tubes (Vacutainer; BectonDickinson, Grenoble, France) for storage before ${ }^{13} \mathrm{C}$ enrichment analysis. The rate of expired $\mathrm{CO}_{2}$ tended to be less in $\mathrm{PI}+$ group during the basal period $(8.3 \pm 1.4$ and $11.5 \pm 0.9 \mathrm{mmol} / \mathrm{min}$ in groups $\mathrm{PI}+$ and $\mathrm{PI}-$, respectively, $P=0.08$; each individual value was the mean of 3 measurements). It was not modified by amino acid-glucose infusion $(9.0 \pm 1.8$ and $11.5 \pm 0.5 \mathrm{mmol} / \mathrm{min}, P=0.2$; means of 4 measurements).

Analysis of ${ }^{13} \mathrm{C}$ enrichment. Plasma L- $\left[1-{ }^{13} \mathrm{C}\right]$ leucine and $\left[{ }^{13} \mathrm{C}\right] \alpha-$ ketoisocaproic acid (KIC) enrichments were determined by GC-MS. Leucine was extracted with chloroform-acetone and KIC with dichloromethane acid (10). Tert-butyldimethylsilyl derivatives of leucine and KIC were prepared from plasma extracts, as described previously (10), and analyzed by GC-electron impact mass spectrometry (mass selective detector 5972, coupled with a gas chromatograph 5890 series II; Hewlett Packard, Les Ullis, France), and the ions were monitored with mass-to-charge ratio 302,303 ([ $\left.{ }^{13} \mathrm{C}\right]$ leucine). Breath ${ }^{13} \mathrm{CO}_{2}$ enrichments were measured directly by isotopic ratio mass spectrometry, using a VG Isochrom (Micromass HK, Manchester, UK).

Assays. The concentrations of free plasma amino acids were measured by ion exchange chromatography. A special protein precipitation protocol was developed to avoid sample dilution. Two hundred fifty microliters of a sulfosalicylic acid solution $(0.916 \mathrm{~mol} / \mathrm{l}$ dissolved in ethanol with $0.533 \mathrm{~mol} / \mathrm{l}$ thiodiglycol and $1.040 \mathrm{mmol} / \mathrm{l}$ norleucine) were added to tubes and evaporated to dryness. One milliliter of plasma was then added to tubes and incubated on ice for $1 \mathrm{~h}$. The samples were then centrifuged for $1 \mathrm{~h}\left(3,500 \mathrm{~g}, 4^{\circ} \mathrm{C}\right)$, and $500 \mu \mathrm{l}$ of supernatant were added to $250 \mu \mathrm{l}$ of $0.1 \mathrm{M}$ lithium acetate buffer, $\mathrm{pH}$ 2.2. Amino acid concentration was determined using an automated amino acid analyzer (Biotronic LC 3000, with BTC 2410 resin; Roucaire, Velizy, France). Plasma tryptophan was determined using a fluorometric method (5) and an LS30 (PerkinElmer, Buckinghamshire, UK).

Plasma substrates were determined on an automatic analyzer (Chem 1; Bayer Diagnostics, Puteaux, France), using enzymes (hexokinase and glucose-6-phosphate dehydrogenase for glucose; urease and glutamate dehydrogenase for urea; cholesterol esterase, cholesterol oxidase, and peroxidase for cholesterol; lipase, glycerokinase, pyruvate kinase, and lactate dehydrogenase for triglycerides).

Retinol-binding protein, $\alpha 1$-acid glycoprotein, C-reactive protein, and fibrinogen were measured by immunonephelometry, using routine hospital assays. Plasma insulin and total plasma testosterone levels were determined by chemiluminescent immunoassay, using commercial kits (Immulite; Diagnostic Products, Los Angeles, CA).

Calculations. Whole body leucine kinetics were calculated using samples taken during the last hour of the basal (at 130, 150, and 180 min) and infused periods (at 260, 280, 300, and $320 \mathrm{~min}$ ). After checking of the isotopic steady state for the last hour of each period (see below), mean plateau enrichment values were used to calculate leucine kinetics.

Total whole body leucine turnover rate $\left(Q, \mu \mathrm{mol} \cdot \mathrm{kg}^{-1} \cdot \mathrm{min}^{-1}\right)$ was determined using the equation $(28,25,41,43,44)$

$$
Q=\mathrm{F} \times \mathrm{IE}_{\text {inf }} / \mathrm{IEa}
$$

where $\mathrm{F}$ is the $\mathrm{L}-\left[1{ }^{13} \mathrm{C}\right]$ leucine infusion rate (in $\mu \mathrm{mol} \cdot \mathrm{kg}^{-1} \cdot \mathrm{min}^{-1}$ ), $\mathrm{IE}_{\mathrm{inf}}$ is the isotopic enrichment of the infusate (i.e., 99 molar percent excess), and IEa (also in molar percent excess) is the plasma $\mathrm{L}-\left[1-{ }^{13} \mathrm{C}\right]$ leucine enrichment. Note that $Q$ includes the tracer infusion.

Whole body leucine flux oxidation $\left(\mathrm{Ox}, \mu \mathrm{mol} \cdot \mathrm{kg}^{-1} \cdot \mathrm{min}^{-1}\right)$ was calculated using either plasma $\mathrm{L}-\left[1-{ }^{13} \mathrm{C}\right]$ leucine or $\left[{ }^{13} \mathrm{C}\right] \mathrm{KIC}$ enrichments from the following equation:

$$
\mathrm{Ox}={ }^{13} \mathrm{CO}_{2} \text { production }(\mu \mathrm{mol} / \mathrm{min}) / \mathrm{IEa} / \mathrm{kg}
$$

where ${ }^{13} \mathrm{CO}_{2}$ production $(\mu \mathrm{mol} / \mathrm{min})=\dot{\mathrm{V}} \mathrm{CO}_{2}\left(\mu \mathrm{mol}\right.$ of $\left.\mathrm{CO}_{2} / \mathrm{min}\right) \times$ $\mathrm{IECO}_{2} \times 1 / \mathrm{R}, \mathrm{IECO}_{2}$ (molar percent excess) is the expired ${ }^{13} \mathrm{CO}_{2}$ enrichment, and $\mathrm{R}(80 \%)$ is a factor correcting for incomplete recovery of labeled bicarbonate (1). IEa represents either the plasma $\mathrm{L}-\left[1-{ }^{13} \mathrm{C}\right]$ leucine or the plasma $\left[{ }^{13} \mathrm{C}\right] \mathrm{KIC}$ enrichments. Because oxidative leucine disposal rate is a function of the rate of ${ }^{13} \mathrm{CO}_{2}$ production, which is the product of the volume of $\mathrm{CO}_{2}$ expired $\times{ }^{13} \mathrm{C}$ enrichment of expired $\mathrm{CO}_{2}$, we checked that this product reached a steady state during the basal and infused periods by testing for the absence of a significant slope when analyzed with linear regression. Originally, we had nine patients in the PI + group, but unfortunately the determination of this isotopic steady state led us to exclude two subjects because their ${ }^{13} \mathrm{CO}_{2}$ production did not reach a steady state during $\left[{ }^{13} \mathrm{C}\right]$ leucine infusion.

According to the model, the following equation applies:

$$
Q=\mathrm{F}+\mathrm{I}+\mathrm{R}_{\mathrm{a}}=\mathrm{Ox}+\mathrm{R}_{\mathrm{d}}
$$

where $\mathrm{F}$ is the $\mathrm{L}-\left[1-{ }^{13} \mathrm{C}\right]$ leucine infusion rate, $\mathrm{I}$ is the rate of intravenous unlabeled leucine infusion ( $I=0$ in the basal period), $R_{a}$ is the endogenous leucine appearance rate (an index of protein breakdown), and $R_{d}$ is the nonoxidative leucine disposal rate (an index of protein synthesis) from plasma (all in $\mu \mathrm{mol} \cdot \mathrm{kg}^{-1} \cdot \mathrm{min}^{-1}$ ).

Knowing $Q, \mathrm{~F}, \mathrm{I}$, and $\mathrm{Ox}$ :

$$
\mathrm{R}_{\mathrm{a}}\left(\mu \mathrm{mol} \cdot \mathrm{kg}^{-1} \cdot \mathrm{min}^{-1}\right)=Q-(\mathrm{F}+\mathrm{I})
$$


and

$$
\mathrm{R}_{\mathrm{d}}\left(\mu \mathrm{mol} \cdot \mathrm{kg}^{-1} \cdot \min ^{-1}\right)=Q-\mathrm{Ox}
$$

with Ox calculated with either plasma $\mathrm{L}-\left[1-{ }^{13} \mathrm{C}\right]$ leucine or plasma $\left[{ }^{13} \mathrm{C}\right] \mathrm{KIC}$ enrichments.

Net leucine balance, an index of protein deposition, is calculated as $R_{d}-R_{a}$. The whole body leucine kinetics rates were expressed per kilogram of fat-free mass $\left(\mu \mathrm{mol} \cdot \mathrm{kg} \mathrm{FFM}{ }^{-1} \cdot \mathrm{min}^{-1}\right.$ ) because the PI+ group had lower FFM than the PI- group.

Statistical analysis. All data are expressed as means \pm SE. Paired $t$-tests were used to compare data obtained during the basal and the amino acid-glucose infusion periods. A two-way ANOVA (main effect therapy of patients and amino acid-glucose infusion) and an unpaired Student's $t$-test were also used to compare the results in PI+ and $\mathrm{PI}-$ groups. $P<0.05$ was considered to be significant.

\section{RESULTS}

Characteristics of the patients. The two groups did not differ with respect to age, height, body weight, and body mass index (Tables 1 and 2). The dual-energy X-ray absorptiometry (Table 2) (37) showed that FFM tended to be lower in the PI+ than in the PI- group $(P=0.07)$. It became significant when expressed in percentage of total body weight. The body fat mass (BFM) was therefore higher in the PI+ than in the PI- group $(P=0.06$ when expressed in $\mathrm{kg}, P=0.005$ when expressed in $\%$ total body wt). As is shown in Table 2, the distribution of BFM clearly differed between groups. There was an accumulation of abdominal BFM in the PI+ group $(57.3 \pm 1.4 \mathrm{vs}$. $42.9 \pm 2.1 \%$ of total BFM in the PI+ group and PI - group, respectively; $P<0.05$ ) associated with a loss of BFM in the arms $(9.7 \pm 0.4$ vs. $11.7 \pm 0.5 \%$ of total BFM in the PI+ group and PI - group, respectively; $P<0.05)$ and legs $(26.9 \pm$ 1.4 vs. $35.5 \pm 2.1 \%$ of total BFM in the PI+ group and PIgroup, respectively; $P<0.05)$. PI + patients had a significantly higher trunk-to-appendicular fat mass ratio than PI- subjects (Table 2), which confirmed trunk adiposity in the PI+ group. A ratio of trunk-to-appendicular fat tissue equaling 1.1 was used to identify subjects with trunk adiposity at baseline (42). All seven of the PI+ patients presented a trunk-to-appendicular fat mass ratio $>1.1(1.23-1.95)$, whereas only one PI - patient had such an elevated value (0.63-1.31).

Total plasma testosterone levels were not significantly different between the two groups (Table 3). Plasma protein contents, indicators of the nutritional state (albumin, prealbumin, retinol-binding protein) and/or the inflammatory state

Table 2. Regional lean and adipose tissue masses in HIV-infected PI+ or PI- patients

\begin{tabular}{lccl}
\hline \hline & PI - & PI & $P$ Value \\
\hline Body weight & $72.7 \pm 5.3$ & $69.8 \pm 1.7$ & 0.62 \\
Whole body lean mass & $62.0 \pm 3.6$ & $54.4 \pm 1.1$ & 0.065 \\
\% Total body weight & $85.9 \pm 1.7$ & $78.0 \pm 1.8 *$ & 0.008 \\
Trunk lean mass & $29.6 \pm 1.7$ & $26.7 \pm 0.6$ & 0.15 \\
Arm lean mass & $7.9 \pm 0.5$ & $6.2 \pm 0.2^{*}$ & 0.015 \\
Leg lean mass & $20.8 \pm 1.4$ & $18.0 \pm 0.6$ & 0.09 \\
Whole body fat mass & $10.6 \pm 1.5$ & $14.8 \pm 1.4$ & 0.063 \\
$\quad$ \% Total body weight & $14.2 \pm 1.1$ & $21.1 \pm 1.7 *$ & 0.005 \\
Trunk fat mass & $4.7 \pm 0.9$ & $8.6 \pm 1.0 *$ & 0.016 \\
Arm fat mass & $1.3 \pm 0.2$ & $1.4 \pm 0.1$ & 0.58 \\
Leg fat mass & $3.7 \pm 0.4$ & $3.9 \pm 0.3$ & 0.66 \\
Trunk-to-appendicular fat mass ratio & $0.92 \pm 0.07$ & $1.59 \pm 0.09 *$ & 0.0001 \\
\hline
\end{tabular}

Values are means $\pm \mathrm{SE}$ in $\mathrm{kg} . * P<0.05$
Table 3. Baseline biochemical variables of HIV-infected $\mathrm{PI}+$ or PI- patients

\begin{tabular}{lcc}
\hline \hline & PI- & PI+ \\
\hline Plasma insulin, mUI/l & $6.09 \pm 2.05$ & $7.24 \pm 1.58$ \\
Plasma glucose, mM & $4.43 \pm 0.31$ & $4.61 \pm 0.30$ \\
Total plasma testosterone, ng/dl & $542 \pm 77$ & $401 \pm 73$ \\
Total cholesterol, mmol/1 & $4.47 \pm 0.46$ & $5.42 \pm 0.40$ \\
Triglycerides, mmol/l & $0.88 \pm 0.22$ & $2.20 \pm 0.31 *$ \\
Prealbumin, g/l & $0.25 \pm 0.02$ & $0.24 \pm 0.02$ \\
Albumin, g/l & $41.00 \pm 0.74$ & $38.34 \pm 1.36$ \\
Retinol binding protein, mg/l & $39.60 \pm 5.11$ & $40.55 \pm 3.94$ \\
$\alpha_{1}$-Acid glycoprotein, g/l & $0.69 \pm 0.04$ & $0.73 \pm 0.09$ \\
C-reactive protein, mg/l & $2.81 \pm 0.53$ & $3.32 \pm 0.12$ \\
Fibrinogen, g/l & $3.16 \pm 0.19$ & $3.54 \pm 0.46$ \\
\hline
\end{tabular}

Values are means $\pm \mathrm{SE} ; n=7$ each in PI - and $\mathrm{PI}+$ groups. $* P<0.05 \mathrm{PI}+$ compared with PI-.

( $\alpha 1$-acid glycoprotein, fibrinogen, and C-reactive protein), were also normal and did not differ between the two groups. Plasma cholesterol was normal and did not differ between the two groups. By contrast, triglycerides were higher in the PI+ than in the PI - group $(P<0.05)$. Basal plasma insulin and glucose concentrations were not significantly different between the two groups (Table 3). Amino acid-glucose infusion increased plasma insulin in both groups $(P<0.05$ vs. basal values). This increase tended to be more pronounced in PI+ patients $(18.4 \pm 2.3$ and $11.2 \pm 2.6 \mathrm{mUI} / 1$ in the PI+ group and $\mathrm{PI}-$ group, respectively; $P=0.06$ ). Plasma glucose also significantly increased during amino acid-glucose infusion $(5.3 \pm 0.3$ and $5.4 \pm 0.2 \mathrm{mmol} / \mathrm{l}$ in $\mathrm{PI}+$ group and $\mathrm{PI}-$ group, respectively) but remained similar in both groups.

Plasma essential free amino acid concentrations were similar in the PI+ and PI - groups during the basal period (Table 4), except for histidine, which was significantly higher in the PI+ than in the PI- group. Amino acid-glucose infusion significantly increased most essential plasma amino acids in both groups, except for threonine, which was not significantly increased in the PI- group. Most amino acids reached similar levels under infusion in the PI + and PI - groups, except for histidine, which was increased at higher levels in the PI+

Table 4. Plasma essential amino acids concentrations in HIV-infected PI+ or PI- patients

\begin{tabular}{lccccc}
\hline \hline & \multicolumn{2}{c}{ Basal Period } & & \multicolumn{2}{c}{ Infused Period } \\
\cline { 2 - 3 } \cline { 5 - 6 } \multicolumn{1}{c}{ Groups } & PI- & PI + & & PI- & PI+ \\
\hline Threonine & $102 \pm 11$ & $95 \pm 10$ & & $115 \pm 7$ & $115 \pm 13^{*}$ \\
Valine & $210 \pm 14$ & $212 \pm 23$ & & $260 \pm 22^{*}$ & $282 \pm 27^{*}$ \\
Methionine & $15 \pm 3$ & $12 \pm 1$ & & $19 \pm 3^{*}$ & $19 \pm 2^{*}$ \\
Isoleucine & $57 \pm 4$ & $58 \pm 9$ & & $84 \pm 8^{*}$ & $105 \pm 8^{*}$ \\
Leucine & $151 \pm 8$ & $146 \pm 18$ & & $198 \pm 14^{*}$ & $220 \pm 15^{*}$ \\
Phenylalanine & $51 \pm 3$ & $52 \pm 8$ & & $66 \pm 3^{*}$ & $71 \pm 6^{*}$ \\
Lysine & $161 \pm 12$ & $146 \pm 13$ & & $249 \pm 20^{*}$ & $260 \pm 5^{*}$ \\
Histidine & $69 \pm 1$ & $77 \pm 3 \dagger$ & & $85 \pm 3^{*}$ & $100 \pm 5^{* \dagger}$ \\
Arginine & $73 \pm 10$ & $69 \pm 4$ & & $110 \pm 18^{*}$ & $112 \pm 7^{*}$ \\
Tryptophan & $66 \pm 9$ & $64 \pm 23$ & & $96 \pm 13^{*}$ & $99 \pm 29^{*}$ \\
Total EAA & $954 \pm 53$ & $932 \pm 55$ & & $1,282 \pm 87^{*}$ & $1,383 \pm 49^{*}$ \\
\hline
\end{tabular}

Values $(\mu \mathrm{mol} / \mathrm{l})$ are means \pm SE. EAA, essential amino acids. Each individual was the mean at 130,150 , and 170 min during the basal period and 260, 280, 300, and $320 \mathrm{~min}$ during amino acid-glucose infusions (infused period). $* P<0.05$, infused vs. basal period in the same group. $\dagger P<0.05$, PI + group vs. PI- group, for the same period. 
group $(P<0.05)$. The absolute incremental increase (infused values - basal values) of total plasma essential amino acids was not significantly higher in the PI+ than in the PI- group during amino acid-glucose infusion. However, it was greater in the PI+ than in the PI- group for leucine $(74.2 \pm 5.5$ vs. $+46.8 \pm 7.9 \mu \mathrm{mol} / \mathrm{l} ; P<0.05)$ and isoleucine $(46.6 \pm 2.5 \mathrm{vs}$. $+27.5 \pm 4.5 \mu \mathrm{mol} / \mathrm{l} ; P<0.05)$.

Whole body leucine kinetics. A steady state of ${ }^{13} \mathrm{CO}_{2}$ production [volume of $\mathrm{CO}_{2}$ expired $(\mu \mathrm{mol} / \mathrm{min}) \times{ }^{13} \mathrm{CO}_{2}$ enrichment $]$ and plasma $\left[{ }^{13} \mathrm{C}\right]$ leucine or $\left[{ }^{13} \mathrm{C}\right] \mathrm{KIC}$ enrichments was achieved (Fig. 2) during the final hour of basal (i.e., 130-180 $\mathrm{min})$ and infused (260-320 min) periods. The mean coefficients of variation for plasma ${ }^{13} \mathrm{C}$ leucine enrichments were 4.4 and $6.1 \%$ during the basal period and 6.6 and $5.2 \%$ during the infused period in the PI- group and PI+ group, respectively. It was 4.1 and $3.6 \%$ during the basal period and 3.8 and $3.3 \%$ during the infused period in the PI- group and PI+ group, respectively, for plasma $\left[{ }^{13} \mathrm{C}\right] \mathrm{KIC}$ enrichments.

At the basal state, ${ }^{13} \mathrm{CO}_{2}$ production, plasma $\left[{ }^{13} \mathrm{C}\right]$ leucine, and plasma $\left[{ }^{13} \mathrm{C}\right] \mathrm{KIC}$ enrichments were not significantly different between the two groups. Amino acid-glucose infusion significantly increased ${ }^{13} \mathrm{CO}_{2}$ production in both groups $(P<$

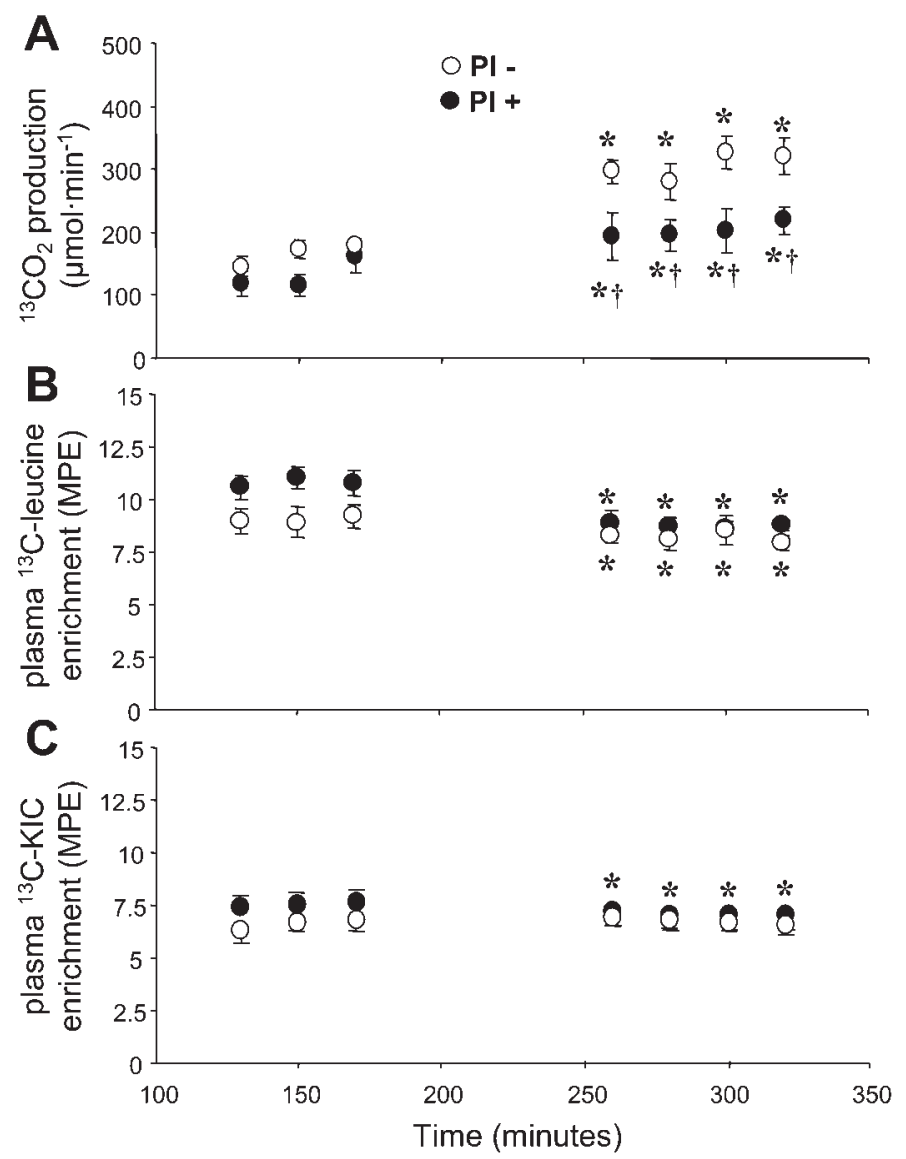

Fig. $2 .{ }^{13} \mathrm{CO}_{2}$ production (product of the volume of expired $\mathrm{CO}_{2} \times$ expired ${ }^{13} \mathrm{CO}_{2}$ enrichments) in $\mu \mathrm{mol} / \mathrm{min}(A),{ }^{13} \mathrm{C}$ enrichment of plasma leucine in molar percent excess (MPE; B), or ${ }^{13} \mathrm{C}$ enrichement of plasma $\left[{ }^{13} \mathrm{C}\right] \alpha-$ ketoisocaproic acid $(\mathrm{KIC} ; C)$ as function of time in human immunodeficiency virus (HIV)-infected patients treated with protease inhibitors (PI+) or without PIs (PI -$)$ in the basal state (130-170 $\mathrm{min}$ ) and during amino acid-glucose infusions (260-320 min). Values are means \pm SE. $* P<0.05$ infused vs. basal period in the same group; $\uparrow P<0.05 \mathrm{PI}+\mathrm{vs}$. PI - in the same period.
$0.05)$, but to a greater extent in the PI- than in the PI+ group (Fig. 2A). Conversely, plasma $\left[{ }^{13} \mathrm{C}\right]$ leucine enrichments decreased under amino acid-glucose infusion in the two groups (Fig. $2 B$ ), but this decrease was more pronounced in the PI+ than in the PI- group $(P=0.0003$ in the PI+ group vs. $P=$ 0.03 in the PI- group, respectively). Plasma $\left[{ }^{13} \mathrm{C}\right] \mathrm{KIC}$ enrichments significantly decreased under amino acid-glucose infusion in the PI+ group (Fig. 2C).

Basal leucine kinetics. During the basal period, PI therapy did not significantly change the total leucine flux $(2.37 \pm 0.12$ and $2.18 \pm 0.13 \mu \mathrm{mol} \cdot \mathrm{kg} \mathrm{FFM}{ }^{-1} \cdot \mathrm{min}^{-1}$ in the PI - group and PI + group, respectively). Similarly, endogenous leucine appearance (an index of protein breakdown), nonoxidative leucine disposal (an index of protein synthesis), and oxidative leucine disposal did not differ significantly between groups during the basal period with the use of either plasma $\left[{ }^{13} \mathrm{C}\right]$ leucine (Fig. 3) or $\left[{ }^{13} \mathrm{C}\right] \mathrm{KIC}$ enrichments (not shown). Basal leucine balance (Fig. 4) was negative in both groups. However, it was less negative in patients treated with PIs $\left(-0.074 \pm 0.039\right.$ vs. $-0.186 \pm 0.032 \mu \mathrm{mol} \cdot \mathrm{kg} \mathrm{FFM}^{-1} \cdot \mathrm{min}^{-1}$ in the PI+ group and PI- group, respectively, with plasma $\left[{ }^{13} \mathrm{C}\right]$ leucine enrichment or $-0.186 \pm 0.050$ vs. $-0.336 \pm$ 0.043 with plasma $\left[{ }^{13} \mathrm{C}\right] \mathrm{KIC}$ enrichment, $P<0.05$ ).

Effect of acute amino acid-glucose infusion. Amino acidglucose infusion significantly increased the total leucine flux in both groups $(2.58 \pm 0.05$ and $2.70 \pm 0.16 \mu \mathrm{mol} \cdot \mathrm{kg}$ FFM ${ }^{-1} \cdot \mathrm{min}^{-1}$ in the PI- group and PI+ group, respectively; $P<$ 0.05 vs. basal period). By contrast, amino acid-glucose infusion significantly decreased the endogenous leucine appearance (Fig. 3A). Amino acid-glucose infusion significantly increased $(P<0.05)$ the oxidative leucine disposal in both groups, with the use use of either plasma $\left[{ }^{13} \mathrm{C}\right]$ leucine (Fig. $3 B$ ) or plasma $\left[{ }^{13} \mathrm{C}\right] \mathrm{KIC}$ enrichments $(0.704 \pm 0.102$ and $0.433 \pm$ $0.071 \mu \mathrm{mol} \cdot \mathrm{kg} \mathrm{FFM}{ }^{-1} \cdot \mathrm{min}^{-1}$ during the infused period and basal period, respectively, in the PI+ group vs. $0.994 \pm 0.078$ and $0.549 \pm 0.041 \mu \mathrm{mol} \cdot \mathrm{kg} \mathrm{FFM}^{-1} \cdot \mathrm{min}^{-1}$ during the infused period and basal period, respectively, in the PI- group). Leucine oxidation during infusion was less in PI+ than in PIpatients $\left(0.58 \pm 0.09\right.$ and $0.81 \pm 0.07 \mu \mathrm{mol} \cdot \mathrm{kg} \mathrm{FFM}^{-1} \cdot \mathrm{min}^{-1}$ in the PI+ group and PI- group, respectively; $P=0.06$ with $\left[{ }^{13} \mathrm{C}\right]$ leucine, $P=0.04$ with $\left.\left[{ }^{13} \mathrm{C}\right] \mathrm{KIC}\right)$. Consequently, the nonoxidative leucine disposal (Fig. $3 C$ ) was higher in patients treated with PIs than in patients treated without PIs $(2.12 \pm$ 0.11 vs. $1.78 \pm 0.06 \mu \mathrm{mol} \cdot \mathrm{kg} \quad \mathrm{FFM}^{-1} \cdot \mathrm{min}^{-1}$ with $\left[{ }^{13} \mathrm{C}\right]$ leucine and $2.0 \pm 0.11$ vs. $1.62 \pm 0.07 \mu \mathrm{mol} \cdot \mathrm{kg}$ $\mathrm{FFM}^{-1} \cdot \mathrm{min}^{-1}$ with $\left[{ }^{13} \mathrm{C}\right] \mathrm{KIC}$ enrichments in the PI+ group and PI- group, respectively; $P<0.05$ ) during the amino acid-glucose infusion. With basal nonoxidative leucine disposal being similar in both groups, the incremental increase (infused values - basal values) in nonoxidative leucine disposal after amino acid-glucose infusion was better in the PI+ than in the PI- group $(0.24 \pm 0.07$ and $-0.20 \pm 0.10$ $\mu \mathrm{mol} \cdot \mathrm{kg} \mathrm{FFM}{ }^{-1} \cdot \mathrm{min}^{-1}$, respectively; $\left.P<0.05\right)$. Indeed, the nonoxidative leucine disposal was increased by amino acidglucose infusion in the PI+ group (1.88 \pm 0.09 vs. $2.12 \pm 0.11$ $\mu \mathrm{mol} \cdot \mathrm{kg} \mathrm{FFM}{ }^{-1} \cdot \mathrm{min}^{-1}$ with $\left[{ }^{13} \mathrm{C}\right]$ leucine or $1.75 \pm 0.09$ vs. $1.99 \pm 0.12 \mu \mathrm{mol} \cdot \mathrm{kg} \mathrm{FFM}{ }^{-1} \cdot \mathrm{min}^{-1}$ with $\left[{ }^{13} \mathrm{C}\right] \mathrm{KIC}$ in the basal period and infused period, respectively; $P<0.05$ ), whereas it tended to decrease in the PI- group $(1.97 \pm 0.11$ vs. $1.78 \pm 0.06 \mu \mathrm{mol} \cdot \mathrm{kg} \mathrm{FFM}^{-1} \cdot \mathrm{min}^{-1}$ with $\left[{ }^{13} \mathrm{C}\right]$ leucine or $1.82 \pm 0.12$ vs. $1.62 \pm 0.07 \mu \mathrm{mol} \cdot \mathrm{kg} \mathrm{FFM}^{-1} \cdot \mathrm{min}^{-1}$ with 


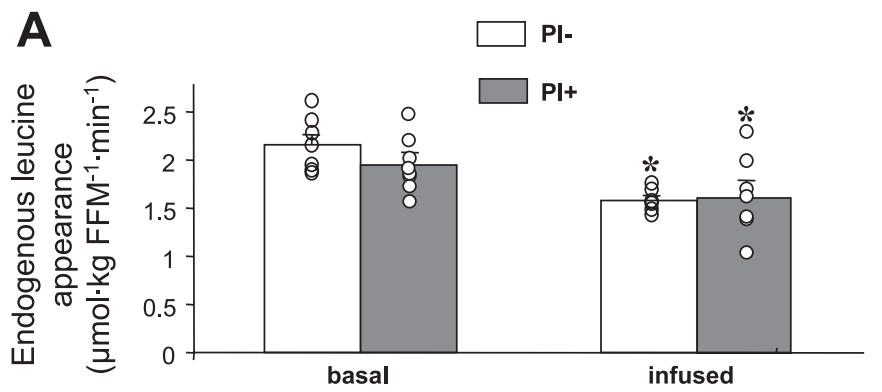

B
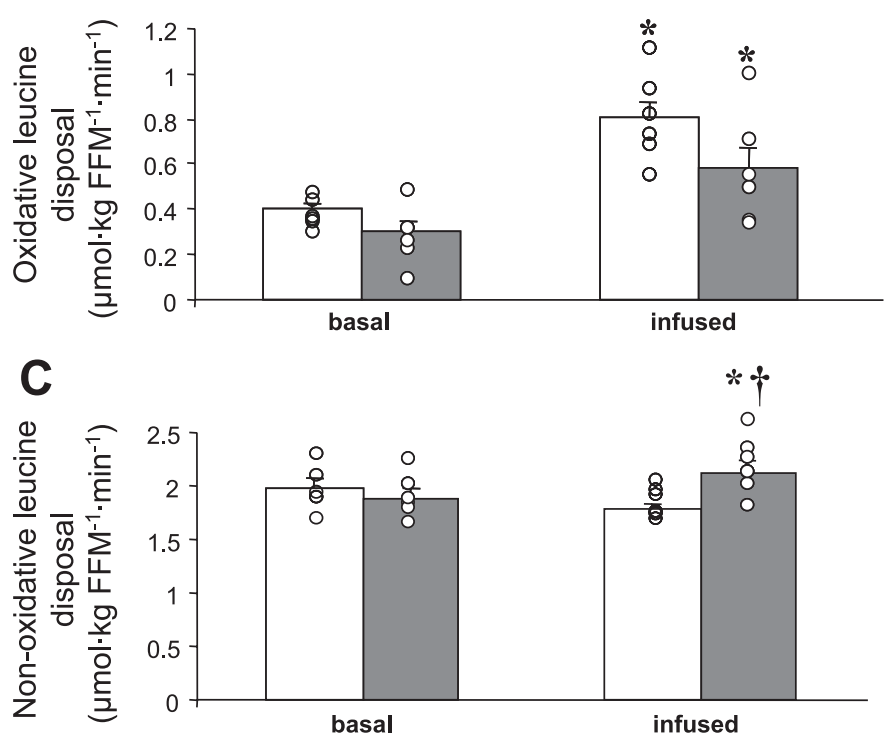

Fig. 3. Whole body leucine kinetics in HIV-infected PI+ and PI- patients during basal and amino acid-glucose infused periods. $A$ : values of endogenous leucine appearance (index of proteolysis); $B$ : oxidative leucine disposal; $C$ : nonoxidative leucine disposal (index of protein synthesis). Values [expressed in $\mu$ mol leucine $\cdot \mathrm{kg}$ fat-free mass $(\mathrm{FFM})^{-1} \cdot \mathrm{min}^{-1}$ ] are means $\pm \mathrm{SE}$ (bars). $\mathrm{O}$, individual values. ${ }^{*} P<0.05$, infused vs. basal period in the same group; $\uparrow P<$ $0.05, \mathrm{PI}+$ vs. $\mathrm{PI}-$ in the same period.

$\left[{ }^{13} \mathrm{C}\right] \mathrm{KIC}$ in the basal period and infused period, respectively; $P=0.1$; Fig. $3 C$ ). As was expected, the net leucine balance showed a switch from negative to positive values by amino acid-glucose infusion in both groups (Fig. 4). However, it became significantly more positive in patients treated with PIs than in patients treated without PIs $(-0.074 \pm 0.040$ to $0.501 \pm 0.099 \mu \mathrm{mol} \cdot \mathrm{kg} \mathrm{FFM}{ }^{-1} \cdot \mathrm{min}^{-1}$ during the basal period and infused period, respectively, in the PI+ group vs. $-0.186 \pm 0.032$ to $0.181 \pm 0.062 \mu \mathrm{mol} \cdot \mathrm{kg} \mathrm{FFM}{ }^{-1} \cdot \mathrm{min}^{-1}$ in the PI- group). The incremental increase in leucine balance (infused values - basal values) was higher in PI+ than in PIpatients $(0.575 \pm 0.064$ and $0.367 \pm 0.071 \mu \mathrm{mol} \cdot \mathrm{kg}$ $\mathrm{FFM}^{-1} \cdot \mathrm{min}^{-1}$ in the PI+ group and PI- group, respectively, $P=0.05)$. These same relative changes were observed by using the plasma $\left[{ }^{13} \mathrm{C}\right] \mathrm{KIC}$ to represent the precursor pool enrichment (data not shown).

\section{DISCUSSION}

Although the introduction of PI treatment in HIV-infected patients has resulted in a pronounced decline in HIV-related morbidity and mortality, it is well recognized that PI therapy is associated with a variety of side effects, including lipid and carbohydrate metabolism disorders. Indeed, lipodystrophy has largely been described in HIV-infected patients receiving PIs $(3,7,19,46)$. Although the loss of lean body mass is still a major problem for patients treated with PIs, protein metabolism has been poorly studied. To our knowledge, the present study is the first to investigate the whole body protein metabolism in HIV-infected patients treated with or without PIs during postabsorptive conditions and during an amino acidglucose infusion.

Despite a limited cross-sectional study, it appears that protease inhibitor-containing regimens may favor whole body protein anabolism in HIV-infected patients.

The improvement in leucine balance during the basal period is indicative of a positive effect of PI treatment on whole body protein anabolism, which suggests a possible limitation of the usual loss of body proteins during the postabsorptive state. Accordingly, a decrease in protein catabolism has recently been reported in fasted HIV-infected prepubertal children receiving PIs (16). Measurements of whole body protein turnover during the amino acid-glucose infusion further suggested this beneficial effect. Indeed, the net leucine balance was clearly higher in PI-treated than in non-PI-treated patients during amino acid-glucose infusion. This marked improvement in the leucine balance with PI treatment was due mainly to an increase in nonoxidative leucine disposal (i.e., protein synthesis) (13-14\% vs. basal, $P<0.05$ in the PI+ group; $-10-11 \%$ vs. basal, not significant in the PI- group).

However, measurements of body composition did not show any increase, but rather a decrease, in body FFM (an index of muscle mass) in PI-treated patients. This means that the effect of PIs on protein metabolism affected organs other than skeletal muscle, e.g., the liver and splanchnic area. It has been shown (30) that intravenous amino acid infusion is able to stimulate protein synthesis in the splanchnic bed of healthy subjects. We might hypothesize that it was also the case in HIV-infected patients. The fact that patients with PIs had a lower FFM than patients without PIs supports the notion that amino acids were utilized to a lesser extent in muscle and were consequently more available in the liver of patients receiving PIs. A specific stimulation of liver protein synthesis in patients treated with PIs is therefore conceivable. Unfortunately, measurements of whole body turnover rate, using the $\left[{ }^{13} \mathrm{C}\right]$ leucine constant infusion method, reflect amino acid metabolism in all proteins of the body and did not allow to discriminate either muscle or liver protein metabolism. An increase in whole body

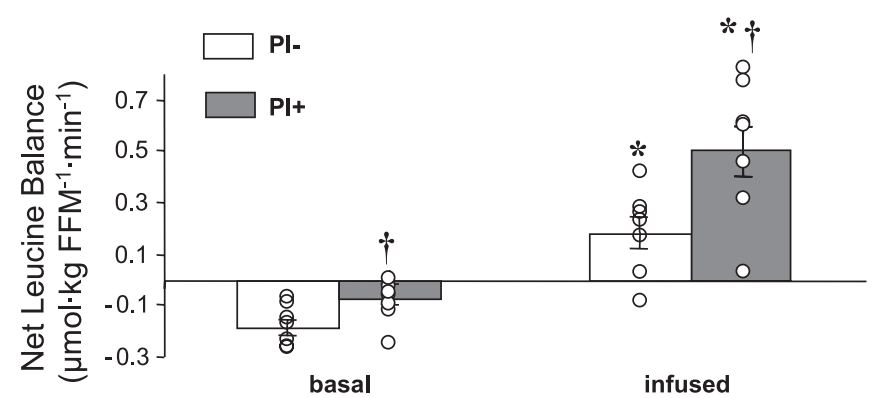

Fig. 4. Leucine balance in HIV-infected PI+ and PI- patients during basal and amino acid-glucose infused periods. Values (expressed in $\mu \mathrm{mol}$ leucine $\cdot \mathrm{kg} \mathrm{FFM}^{-1} \cdot \mathrm{min}^{-1}$ ) are means $\pm \mathrm{SE}$ (bars). $\circ$, individual values. $* P<$ 0.05 , infused vs. basal period in the same group; $\uparrow P<0.05$, PI + vs. PI - in the same period. 
protein synthesis, along with a decrease in muscle mass, has already been reported in AIDS-wasting patients compared with HIV seronegative subjects (48). More recently, the same group reported that reducing plasma HIV RNA improved muscle protein synthesis without increasing muscle mass (47). The failure to restore muscle mass in PI-treated patients, despite the fact that whole body protein synthesis was increased, suggests that muscle protein synthesis could contribute less to the elevated rate of whole body protein synthesis.

Alternatively, this discrepancy allows for other explanations. First, our findings are limited by the fact that we did not know the FFM of the patients before they started their present therapy. Second, the anabolic response observed in the present study was obtained by parenteral "feeding," which avoids the confounding effects of malabsorption presently found in HIVinfected patients, which suggests a best availability of substrates for protein synthesis. Third, the improvement in whole body protein synthesis observed in PI-treated patients occurred during the infusion of a balanced amino acid-glucose mixture (protein synthesis being similar in both groups at the basal state), which suggests that PI therapy should be beneficial in feeding conditions only under adequate amino acid supply. Last, a short-term positive result might not indicate long-term beneficial effects on protein deposition. A modest but significant increase (3\%) in lean body mass has been observed (4) after a 12-wk period of nutritional supplements combined with dietary counseling in HIV-infected patients.

During the intravenous amino acid-glucose infusion, the total whole body leucine flux increased in HIV-infected patients $(10 \%, P<0.05$; and $24 \%, P<0.0001$ in PI - and PI+ patients vs. the basal period). This observation is in agreement with previous data (26), which showed respective increases of 27 and $16 \%$ in the whole body leucine flux during an administration of intravenous nutrition in stages II and IV of HIVinfected subjects compared with the fasted state. Those authors also showed that HIV infection did not quantitatively impair the acute anabolic response to intravenous nutrition compared with control subjects. The present study does not allow for suggesting the same conclusion, because healthy subjects were not included. However, in a previous study, we showed that a similar amino acid-glucose infusion, albeit in the presence of insulin, did not stimulate the nonoxidative leucine disposal in healthy subjects. As was observed in the PI- group in the present study, amino acid-glucose infusion also impaired nonoxidative leucine disposal (-10\%) (41). Moreover, Giordano et al. (14) clearly showed that amino acid infusion, which increased plasma amino acids by $1.25-1.50$ above baseline (as in the present study), did not change nonoxidative leucine disposal in healthy volunteers. Therefore, we can hypothesize that the improvement of whole body protein synthesis by amino acid-glucose infusion might be specific to the PI therapy.

The increase in protein synthesis during amino acid-glucose infusion occurred along with a lower leucine oxidation in patients treated with PIs $(-28 \%)$, using either plasma $\left[{ }^{13} \mathrm{C}\right]$ leucine or $\left[{ }^{13} \mathrm{C}\right] \mathrm{KIC}$ enrichements. These findings support the hypothesis that PI treatment may reduce the amino acid oxidation pathway to spare amino acids for whole body protein synthesis. Leucine concentration in intracellular precursor pools of protein synthesis or leucine degradation may increase differentially in PI+ and PI- patients after infusion. Unfortunately, the leucine transport into these pools was not available.
Alternatively, a selective defect in leucine degradation might be considered, due to the fact that adipose tissue contributes to the degradation of leucine. The KIC is decarboxylated by branched-chain keto acid dehydrogenase (EC 1.2.4.4) to form isovaleryl $\mathrm{CoA}$, which is further oxidized through reactions similar to those by which fatty acyl-CoA is degraded. We might speculate that the PI-induced abnormalities of adipose tissue altered these reactions as well as lipid metabolism (8, 45). Another specific mechanism is that leucine transamination for the synthesis of glutamine may be inhibited. Yarasheski et al. (47) demonstrated that highly active antiretroviral therapy decreased glutamine synthesis. Because PI treatment has been shown to decrease energy expenditure (33), a nonspecific reduction of substrate catabolism could not be excluded. Accordingly, $\mathrm{CO}_{2}$ production was reduced in $\mathrm{PI}+$ compared with $\mathrm{PI}-$ patients.

Amino acid-glucose infusion increased plasma amino acids concentrations in both groups. The mean incremental increase (i.e., infused values - basal values) in essential plasma free amino acids was not significantly different between the two groups despite a trend toward a greater effect in the PI+ than in the PI - group $(53 \pm 8$ vs. $35 \pm 4 \%$ of basal values, $P=$ $0.08)$. When considering individual amino acids, it appears that the incremental increase in plasma leucine and isoleucine during amino acid-glucose infusion was greater in PI + than in $\mathrm{PI}-$ patients. This is consistent with an inhibition of the degradation of these branched-chain amino acids in PI+ patients. Moreover, branched-chain amino acids have been shown to stimulate protein synthesis $(13,29)$, and this might partly explain the stimulation of protein synthesis in PI+ group. It also appears that the incremental increase in threonine was not significant in patients treated without PIs (15\%), whereas it was significant in patients treated with PIs $(20 \%$; $P<0.05)$. The incremental increase in methionine was also smaller in the PI- $(32 \%)$ than in the PI+ $(61 \%)$ group $(P<$ $0.05)$. We can thus hypothesize that these amino acids were less rate limiting for protein synthesis in the PI+ than in the $\mathrm{PI}$ - group. Indeed, in a previous experiment (23), we demonstrated that threonine and possibly methionine might be rate limiting for whole body protein synthesis in HIV-infected patients compared with healthy subjects. Thus these findings suggest that PI therapy decreases the limiting aspect of some amino acids in HIV-infected patients, favoring whole body protein anabolism.

An increase in whole body protein anabolism could be surprising in HIV-infected patients treated with combination regimens, including PIs, because it is recognized that PI-based therapy is associated with a number of metabolic complications, including insulin resistance (19). Insulin sensitivity of patients was not investigated in the present study. In the basal state, some indirect indicators such as fasting plasma insulin and glucose (Table 3), as well as plasma insulin-glucose ratio $(1.52 \pm 0.30$ vs. $1.40 \pm 0.49$ in $\mathrm{PI}+$ and $\mathrm{PI}-$ groups, not significant), did not support an insulin resistance state in either group. However, at the end of amino acid-glucose infusion, plasma insulin tended to be higher in the PI+ than in the PIgroup (Table 3), and the insulin-glucose ratio was significantly increased in PI-treated patients $(3.45 \pm 0.32$ vs. $1.99 \pm 0.38$ in the PI+ group and PI - group, respectively; $P<0.05)$. Taken together, these data may suggest a decrease in insulin sensitivity in PI-treated patients. Such a decrease would not be 
compatible with the increase in whole body protein synthesis obtained in PI+ patients. However, previous studies $(19,32$, 38) that describe insulin resistance as a consequence of PI treatment generally concerned glucose and lipid metabolisms. Indeed, a link between peripheral lipid storage and insulin sensitivity has been suggested (6). Therefore, the increase in whole body protein synthesis and leucine balance observed in $\mathrm{PI}+$ compared with PI- patients resulted presumably from insulin-independent mechanisms. Accordingly, the dose-response curves for protein synthesis as a function of plasma insulin showed that the maximum insulin effect was obtained at very low insulin levels (12), and an additional increase in plasma insulin did not further increase protein synthesis. In other words, insulin appears to be a rather permissive modulator for protein synthesis $(34,36)$.

Our data suggest that highly active antiretroviral therapy, including PIs in HIV-infected patients, might favor whole body protein anabolism compared with antiretroviral therapy without PIs. The mechanisms involved in such an effect are not clear. Indeed, a recent report (18) showed that PIs, and especially indinavir, impaired protein synthesis in mouse $\mathrm{C}_{2} \mathrm{C}_{12}$ myocytes. Whether these changes occur in vivo remains to be determined. Alternatively, NRTIs are known to induce mitochondrial toxicity, which subsequently leads to mitochondrial DNA depletion and dysfunction of the respiratory chain (i.e., decreased ATP synthesis). We can hypothesize that such alterations might influence protein metabolism because both protein synthesis and degradation require ATP. Moreover, it has been shown that NRTI toxicity is associated with hyperlactatemia and lactic acidosis $(25,27)$, which could alter protein metabolism. Acute or chronic acidosis has been shown to increase whole body proteolysis and decrease protein balance $(2,9)$. Although all patients received NRTIs (Table 1), the toxic effects of NRTIs might be more pronounced in PI- than they are in PI+ patients (24) and might have contributed to the lower whole body protein synthesis and leucine balance observed in PI- compared with PI+ patients.

In conclusion, the limited patient number of this crosssectional design and some heterogeneity of treatment combinations do not allow for a definitive conclusion on the effect of PIs on protein metabolism in HIV-infected patients. However, we believe that the results of the present study clearly show that whole body protein anabolism was improved in patients treated with PIs (i.e., increase in the nonoxidative leucine disposal and leucine balance), especially in response to an acute amino acid-glucose infusion. However, the absence of an associated increase in lean body mass suggests that it will be necessary to obtain more data to better analyze the effect of PI therapy on protein metabolism, not only in skeletal muscle but also in other potential targets. Whether a possible beneficial effect of PI therapy on lean body mass might occur during long-term, suitable nutritional support remains to be determined.

\section{ACKNOWLEDGMENTS}

We thank the patients for their participation in this study. We thank G. Bayle for amino acids analysis, J. Prugnaud for mass spectrometry assays, and F. Gourdon and O. Baud for their participation in the patients' recruitment and survey. We also thank L. Cormerais for gestion of medical files and S. Jouvency for the dietary control of the patients.

\section{GRANTS}

This work was supported by SIDACTION, the Région Auvergne, and grants from Clintec Technologies, Velizy, France.

\section{REFERENCES}

1. Allsop JR, Wolfe RR, and Burke JF. Tracer priming the bicarbonate pool. J Appl Physiol 45: 137-139, 1978.

2. Ballmer PE and Imoberdorf R. Influence of acidosis on protein metabolism. Nutrition 11: 462-468, 1995.

3. Beatty G, Khalili M, Abbasi T, Chu J, Reaven GM, Rosen A, Schmidt JM, Stansell J, and Koch J. Quantification of insulin-mediated glucose disposal in HIV-infected individuals: Comparison of patients treated and untreated with protease inhibitors. J Acquir Immune Defic Syndr 33: 34-40, 2003.

4. Berneis K, Battegay M, Bassetti S, Nuesch R, Leisibach A, Bilz S, and Keller U. Nutritional supplements combined with dietary counselling diminish whole body protein catabolism in HIV-infected patients. Eur J Clin Invest 30: 87-94, 2000.

5. Bloxam DL and Warren WH. Error in the determination of tryptophan by the method of Denkla and Dewey. A revised procedure. Anal Biochem 60: 621-625, 1974.

6. Boden G and Shulman GI. Free fatty acids in obesity and type 2 diabetes: defining their role in the development of insulin resistance and $\beta$-cell dysfunction. Eur J Clin Invest 32: 14-23, 2002.

7. Carr A, Samaras K, Burton S, Law M, Freund J, Chisholm DJ, and Cooper DA. A syndrome of peripheral lipodystrophy, hyperlipidaemia and insulin resistance in patients receiving HIV protease inhibitors. AIDS 12: F51-F58, 1998.

8. Caron M, Auclair M, Vigouroux C, Glorian M, Forest C, and Capeau J. The HIV protease inhibitor indinavir impairs sterol regulatory elementbinding protein-1 intranuclear localization, inhibits preadipocyte differentiation, and induces insulin resistance. Diabetes 50: 1378-1388, 2001.

9. Caso G, Garlick BA, Casella GA, Sasvary D, and Garlick PJ. Acute metabolic acidosis inhibits muscle protein synthesis in rats. Am J Physiol Endocrinol Metab 287: E90-E96, 2004.

10. Collin-Vidal C, Cayol M, Obled C, Ziegler F, Bommelaer G, and Beaufrère B. Leucine kinetics are different during feeding with whole protein or oligopeptides. Am J Physiol Endocrinol Metab 267: E907E914, 1994.

11. Creen P, Rakotoanbinina B, Raynaud JJ, Thuillier F, Messing B, and Melchior JC. Hyperphagia contributes to the normal body composition and protein-energy balance in HIV-infected asymptomatic men. $J$ Nutr 134: 2301-2306, 2004.

12. Fedele MJ, Hernandez JM, Lang CH, Vary TC, Kimball SR, Jefferson LS, and Farrell PA. Sever diabetes prohibits elevations in skeletal muscle protein synthesis following acute resistance exercise in rats. J Appl Physiol 88: 102-108, 2000.

13. Garlick PJ. The role of leucine in the regulation of protein metabolism. J Nutr 132: 1553S-1556S, 2005.

14. Giordano M, Castellino P, and DeFronzo RA. Differential responsiveness of protein synthesis and degradation to amino acid availability in humans. Diabetes 45: 393-399, 1996.

15. Grinspoon S and Mulligan K. Weight loss and wasting in patients infected with human immunodeficiency virus. Clin Infect Dis 36: S69S78, 2003.

16. Hardin DS, Ellis KJ, Rice J, and Doyle ME. Protease inhibitor therapy improves protein catabolism in prepubertal children with HIV infection. J Pediatr Endocrinol Metab 17: 321-325, 2004.

17. Hardin DS, LeBlanc A, Young D, and Johnson P. Increased leucine turnover and insulin resistance in men with advanced HIV infection. J Investig Med 47: 405-413, 1999.

18. Hong-Brown LQ, Brown CR, and Lang CH. Indinavir impairs protein synthesis and phosphorylations of MAPKs in mouse $\mathrm{C}_{2} \mathrm{C}_{12}$ myocytes. Am J Physiol Cell Physiol 287: C1482-C1492, 2004.

19. Hruz PW, Murata H, and Mueckler M. Adverse metabolic consequences of HIV protease inhibitor therapy: the search for a central mechanism. Am J Physiol Endocrinol Metab 280: E549-E553, 2001.

20. Jahoor F, Abramson S, and Heird WC. The protein metabolic response to HIV infection in young children. Am J Clin Nutr 78: 182-189, 2003.

21. Kotler DP, Tierney AR, Wang J, and Pierson RN. Magnitude of body cell mass depletion and the timing of death from wasting in AIDS. Am J Clin Nutr 50: 444-447, 1989. 
22. Kotler DP, Wang J, and Pierson RN. Body composition studies in patients with the acquired immunodeficiency syndrome. Am J Clin Nutr 42: 1255-1265, 1985.

23. Laurichesse H, Tauveron I, Gourdon F, Cormerais L, Champredon C, Charrier S, Rochon C, Lamain S, Bayle G, Laveran H, Thieblot $P$, Beytout J, and Grizard J. Threonine and methionine are limiting amino acids for protein synthesis in patients with AIDS. J Nutr 128: 1342-1348, 1998.

24. Lee H, Hanes J, and Johson KA. Toxicity of nucleoside analogues used to treat AIDS and the selectivity of the mitochondrial DNA polymerase. Biochemistry 42: 14711-14719, 2003.

25. Lewis W, Copeland WC, and Day BJ. Mitochondrial DNA depletion, oxidative stress, and mutation: mechanisms of dysfunction from nucleoside reverse transcriptase inhibitors. Lab Invest 81: 777-790, 2001.

26. Macallan DC, McNurlan MA, Milne E, Calder AG, Garlick PJ, and Griffin GE. Whole-body protein turnover from leucine kinetics and the response to nutrition in human immunodeficiency virus infection. Am J Clin Nutr 61: 818-826, 1995.

27. Marceau G, Sapin V, Jacomet C, Ughetto S, Cormerais L, Regagnon C, Dastugue B, Peigue-Lafeuille $\mathbf{H}$, Beytout $\mathbf{J}$, and Laurichesse $\mathbf{H}$. Frequency, risk factors, and outcome of hyperlactatemia in HIV-positive persons: implications for the management of treated patients. Clin Chem 49: $1154-1162,2003$.

28. Matthews DE, Motil KJ, Rohrbaugh DK, Burke JF, Young VR, and Bier DM. Measurement of leucine metabolism in man from a primed, continuous infusion of L- $\left[1-{ }^{13} \mathrm{C}\right]$ leucine. Am J Physiol Endocrinol Metab 238: E473-E479, 1980.

29. Nair SK and Short KR. Hormonal and signaling role of branched-chain amino acids. J Nutr 135: 1547S-1552S, 2005.

30. Nygren $\mathbf{J}$ and Nair KS. Differetial regulation of protein dynamics in splanchnic and skeletal muscle beds by insulin and amino acids in healthy human subjects. Diabetes 52: 1377-1385, 2003

31. Paton NI, Ng YM, Chee CB, Persaud C, and Jackson AA. Effects of tuberculosis and HIV infection on whole-body protein metabolism during feeding, measured by the $[15 \mathrm{~N}]$ glycine method. Am J Clin Nutr 78: 319-325, 2003.

32. Penzak SR and Chuck SK. Hyperlipidemia associated with HIV protease inhibitor use: pathophysiology, prevalence, risk factors and treatment. Scand J Infect Dis 32: 111-123, 2000.

33. Pernerstorfer-Schoen H, Schindler K, Parschalk B, Schindl A, Thoeny-Lampert S, Wunderer K, Elmadfa I, Tschachler E, and Jilma B. Beneficial effects of protease inhibitors on body composition and energy expenditure: a comparison between HIV-infected and AIDS patients. AIDS 13: 2389-2396, 1999.

34. Prod'homme M, Rieu I, Balage M, Dardevet D, and Grizard J. Insulin and amino acids both strongly participate to the regulation of protein metabolism. Curr Opin Clin Nutr Metab Care 7: 71-77, 2004.
35. Reeds PJ. Isotopic estimation of protein synthesis and proteolysis in vivo. In: Modern Methods in Protein Nutrition and Metabolism, edited by Nissen S. San Diego, CA: Academic, 1992, p. 249-273.

36. Rennie MJ, Bohé J, and Wolfe RR. Latency, duration and dose response relationships of amino acid effects on human muscle protein synthesis. $J$ Nutr 132: 3225S-3227S, 2002.

37. Safrin $\mathbf{S}$ and Grunfeld C. Fat distribution and metabolic changes in patients with HIV infection. AIDS 13: 2493-2505, 1999.

38. Salomon J, DeTruchis $\mathbf{P}$, and Melchior JC. Nutrition and HIV infection. Br J Nutr 87: S111-S119, 2002.

39. Selberg O, Süttmann U, Melzer A, Deicher H, Müller MJ, Henkel E, and McMillan DC. Effect of increased protein intake and nutritional status on whole-body protein metabolism of AIDS patients with weight loss. Metabolism 44: 1159-1165, 1995.

40. Stein TP, Nutinsky C, Condoluci D, Schluter MD, and Leskiw MJ. Protein and energy substrate metabolism in AIDS patients. Metabolism 39: 876-881, 1990 .

41. Tauveron I, Charrier S, Champredon C, Bonnet Y, Berry C, Bayle G, Prugnaud J, Obled C, Grizard J, and Thiéblot P. Response of leucine metabolism to hyperinsulinemia under amino acid replacement in experimental hyperthyroidism. Am J Physiol Endocrinol Metab 269: E499E507, 1995.

42. Tebas P, Powderly WG, Claxton S, Marin D, Tantisiriwat W, Teitelbaum SL, and Yarasheski KE. Accelerated bone mineral loss in HIVinfected patients receiving potent antiretroviral therapy. AIDS 14: F63F67, 2000.

43. Tesseraud S, Grizard J, Debras E, Papet I, Bonnet Y, Bayle G, and Champredon C. Leucine metabolism in lactating and dry goats: effect of insulin and substrate availability. Am J Physiol Endocrinol Metab 265: E402-E413, 1993.

44. Watt PW, Lindsay Y, Scrimgeour CM, Chien PA, Gibson JNA, Taylor DJ, and Rennie MJ. Isolation of aminoacyl-tRNA and its labeling with stable-isotope tracers: use in studies of human tissue protein synthesis. Proc Natl Acad Sci USA 88: 5892-5896, 1991.

45. Woerle HJ, Mariuz PR, Meter C, Reichman RC, Popa EM, Dostou JM, Welle SL, and Gerich JE. Mechanisms for the deterioration in glucose tolerance associated with HIV protease inhibitor regimens. Diabetes 52: 918-925, 2003.

46. Yanovski JA, Miller KD, Kino T, Friedman TC, Chrousos GP, Tsigos C, and Falloon J. Endocrine and metabolic evaluation of human immunodeficiency virus-infected patients with evidence of protease inhibitorassociated lipodystrophy. J Clin Endocrinol Metab 84: 1925-1931, 1999.

47. Yarasheski KE, Smith SR, and Powderly WG. Reducing plasma HIV RNA improves muscle amino acid metabolism. Am J Physiol Endocrinol Metab 288: E278-E284, 2005.

48. Yarasheski KE, Zachwieja JJ, Gischler J, Crowley J, Horgan MM, and Powderly WG. Increased plasma Gln and Leu $\mathrm{R}_{\mathrm{a}}$ and inappropriately low muscle protein synthesis rate in AIDS wasting. Am J Physiol Endocrinol Metab 275: E577-E583, 1998. 